\title{
Editorial
}

\section{It's the audit committee, stupid}

On 6th January, 2005, the New York Times reported that ten ex-directors of WorldCom were being required by a settlement to dig into their own pockets to the tune of $\$ 18 \mathrm{~m}$. On the very next day ex-directors of Enron also agreed to personally contribute $\$ 13 \mathrm{~m}$ towards a settlement with creditors. If not technically a first, a near first, ${ }^{1}$ these are precedents that may revolutionise the role of the audit committee as directors, who realise that they now have 'skin in the game' and begin to question their appropriate function in corporate governance. While both WorldCom and Enron are exceptional in representing the biggest bankruptcies in history, it is becoming increasingly conceivable that insurers and lead plaintiff attorneys will pressure directors, where there is evidence of gross negligence, to dig into their own pockets to avoid the travails of protracted litigation. It is especially notable that these developments are based on events before the application of Sarbanes-Oxley, which itself imposes requirements for the first time on the existence, composition and role of the audit committee. Clearly it is time to reconsider the role of the audit committee in the financial reporting process.

In the post-Sarbanes-Oxley era, most proposals for mitigating accounting irregularities have focused on auditors. While I have editorialised that it is time to end the Big Four Accounting Cartel in this column, smaller accounting firms do not have the reach and resources to step up to the plate. Various proposals have attempted to deal with the shortcomings of the Big Four, including limited but strict liability (Professor Coffee), an end to limited liability (Professor
Macey) and financial statement insurance (Professor Ronen). In the UK, the Big Four will soon be protected by overall liability limits, as they will no doubt be in the USA. This is not necessarily a bad outcome. For better or worse, the Big Four are here to stay: not only are they too big to fail but there are too few of them for another one to be allowed to go the way of Arthur Andersen.

But a guaranteed right to exist has serious implications for the ability to hold audit firms accountable for the integrity of financial reporting, as demonstrated by the constrained way in which the Public Company Accounting Oversight Board (PCAOB) has chosen to use the new powers granted to it by the Sarbanes-Oxley Act to inspect the audit industry. In this first round of inspections the PCAOB found misapplications of generally accepted accounting principles (GAAP) in an infinitesimal sampling of engagements (64 out of 10,000 Big Four engagements, and covering only one Emerging Issue Taskforce (EITF) pronouncement among hundreds and amid thousands of pages of rules); the PCAOB is also entering into a dialogue with the Big Four investigating 'tone at the top', getting to know field offices, reviewing procedures for engagement etc. Although the PCAOB may affect 'tone at the top', neither it nor the Big Four can serve as guarantors of financial statements. With Section 404 internal controls coming online shortly, auditing is likely to be roiled by the application of such new procedures.

It is time to put the onus on the proper party which has the expertise and ability to determine the control structure over the 
company's financial reporting process and the authority to hold company officers and the external auditor accountable for their actions: the public company audit committee.

Under Sarbanes-Oxley, the audit committees hire auditors and determine what additional services auditors should provide. Although prohibited from being the makers of internal controls, auditors are demanding that they be involved in the process since they are having difficulty auditing procedures which they did not inaugurate. Indeed, one aspect of the internal control audit is 'the effectiveness of the audit committee'. This puts the audit committee in, depending on whether one considers this a problem or an opportunity, either the hot seat or the driver's seat.

With market capitalisation declining by up to seven or eight hundred times the amount of financial restatements, Fortune 100 companies could live large and pay audit committee members a million apiece in hard cash (after all, the dollar's not worth that much these days). But, even granted sufficient motivation, thousands of audit committee members are wondering what exactly should they be doing? Well, for a start, why not put the audit committee in charge of - auditing! This means the entire process of financial reporting, and is there any aspect of financial reporting that is not covered by internal controls? But the term 'internal controls' as used in Section 404 is at best a misnomer or buzzword and at worst a subterfuge to hide the Congress's misgivings about slaying the goose that laid the golden option or created market mania. Consider the COSO framework, which the SEC cites as an appropriate basis for internal controls. COSO has a great many elements which are tangential to financial reporting. In fact, the framework may be considered to focus on the safeguarding of assets and the designation of current liabilities. But the CEO certification under Sarbanes-Oxley requires a certification by the officer identifying the framework used for internal controls of financial reporting, certifying that the controls are effective and noting any change in internal controls. The Securities and Exchange Commission (SEC) release on internal controls focused on the distinction between internal controls over financial reporting and those over procedures and regulations.

Although there is nothing in Section 404 or SEC rules to require the audit committee to give a hoot about internal controls, the implementation of Auditing Standard No. 2 requires that auditors certify the 'effectiveness of audit committees'. When an ineffective audit committee rises to the level of a significant deficiency in internal controls, much less a material weakness, is anybody's guess at the moment. At one point, experts weighed in with how many hours of work or meetings audit committee members should clock up. With no standards to assess audit committee effectiveness, auditors are at a loss.

What might constitute 'best practice' for audit committees? Ultimately, financial numeracy (literacy) depends on familiarity with a company's financials. Audit committee members should understand how the financial statement is derived, the segments which contribute significantly to profit or loss and the safeguards in place to assure that the proper numbers rise to the fore. So, any large-scale unexplained deviation from expectations should cause the audit committee to question whether the CEO and CFO as well as auditors have broken faith with the audit committee. In most instances involving a restatement, the audit committee should give serious consideration to recommending the early retirement of the $\mathrm{CEO} / \mathrm{CFO}$ and auditors. At the very least, any restatement should give rise to an internal investigation. But the risk of restatement can be reduced by the audit committee making plain to auditors that 
they - not managers - hire and fire auditors (the firing of auditors is not necessarily the responsibility of the audit committee under Sarbanes-Oxley). Also, internal auditors and managers should separately report to managers on the process of financial reporting and the effectiveness of internal controls. Audit committees should be involved in issuing forecasts about quarterly earnings since, in the real world, these estimates drive the determination of actual earnings. Audit committees should also have control over the decision to sue auditors for negligence. To the extent that the audit committee charter reflects such duties and responsibilities, companies will be rewarded by the market since their financial reporting process will be considered more reliable. Most important, if the COSO framework is used to ensure audit committees have an adequate independent process for the verification of internal controls over financial reporting, such committees would presumably be far more likely to be effective.

The main problem is that the typical audit committee only meets a few times a year, but corporate governance can no longer remain a part-time job. Rather, the audit committee must put in place systems that ensure that it can monitor on an ongoing basis the actions of managers and the integrity of the controls under which they operate. The audit committee can remain a part-time operation only as long as company personnel are aware that they are subject full time to its authority and oversight. Emerging technologies, such as continuous assurance, and stronger controls along the line of Section 404 requirements need to be brought together in a comprehensive and integrated fashion in order to give the audit committee the tools it needs to take on broader responsibility for corporate governance.

If the Enron and WorldCom settlements do not serve as sufficient impetus for audit committees to act, the directors and officers (D \& O) insurers will step into the breach. Indeed, they have clearly done so in these cases, but instead of acting after the fact to limit damages, they may soon come to the realisation that they need to assume a greater role ex ante to ensure that the parties they are insuring do not consider insurance a free pass to avoid exercising responsibility. The same reinsurers who cover directors and officers also cover the Big Four, so they will decide what is a 'material weakness' or a 'significant defect' under Section 404 as much as they will determine the effectiveness of internal controls.

Consider the analogous issue of products liability. The EU has scads of regulations about product safety, but in the USA the law is rather laconic and broad. Case law has filled the breach and insurers have spelled out the standards. Sarbanes-Oxley spells out broad officer certifications on financial reporting and internal controls, audit committee hiring of auditors and approval of consulting services by the auditor, audit committee financial expertise and independence, while the Private Securities Litigation Reform Act (PSLRA) provides severe limitations on class action lawsuits. The ultimate negotiation of these boundaries depends in large measure on liability risk, the brunt of which is borne by insurers. Reinsurers are by nature conservative. These days D\&O contracts tend to run for only a year. No doubt reinsurers are waiting to see which way the wind blows. It may take another market downturn to fuel new mega-settlements in public company and auditor liability, bringing with it more definitive case law. Or one reinsurer or another may jump the gun and determine what kind of governance structure will reduce the risk of restatement and correlative litigation. Or a reinsurer somewhere mulling over the age-old agency problem, wondering what auditors, officers or future legislation will do to reduce 
financial overstatements, will have an epiphany and exclaim 'It's the audit committee, stupid!' and demand, in return for reasonable premiums, specific procedures involving the audit committee in the implementation and supervision of internal controls over financial reporting which, in real life, means the application of financial standards to income and expenses.

It seems that the reinsurance industry is about to be put out of the loss mitigation business - where shady devices obscure earnings through insurance products and the risk of loss is not substantively transferred to the insured. Zurich Financial, SwissRe and General Re have been hit with document requests by the SEC (AIG paid a big fine in a case involving Brightpoint and J.P. Morgan Chase in Enron used similar schemes). Regardless of the outcome of these situations, loss mitigation is the insurance product of the past just as clearly as risk mitigation is the product of the future. Risk mitigation financial instruments would involve active changes principally in corporate governance, audit committee charters, internal control design and information and software systems which deliver audit committee verification of 'internal controls over financial reporting', including the application of the Federal Accounting Standards Board (FASB) to the proper preparations and the assurance, although not specifically signed by the audit committee, of audit committee oversight, made more effective by a context for internal controls. If risk is brought down, insurance companies will be willing to take a broader umbrella of exposures (risk transfer through hedging products) which could resuscitate the business. Governance risk mitigation can prove to be a highly profitable product.
No one would suggest that empowering the audit committee would end accounting fraud. A concerted fraud by corporate officers might trump any efforts of part-time audit committee members. But if standard audit committee practices were put in place which provided the members with a framework for understanding their role in the internal control process, understanding how the financial statement is actually put together and the role of inside auditors and consultants, and implementing a COSO report on financial fraud which suggested that audit committee members should pressure management for benchmarks and comparables from companies in similar industries, something of a framework for audit committee standards will begin to develop. To be sure, each company should have its own proprietary system, but a framework could provide ample help. Audit committees might not catch every financial fraud. But that's not their job. Creating a 'tone at the top' which whistleblowers or others with questions find inviting is more than enough. It is not what the audit committee knows that counts. It is what the over-reaching CFO/CEO, whether out on a looting binge or just a little earnings smoothing, believes the audit committee might find out.

\section{REFERENCE}

1 The same 6th May issue cites Professor Klausner of Stanford Law School: there have been four cases in which directors have had to shell out of their own pockets. His colleagues at Stanford Law School in 2003 identified only one situation in which the venture capital firm of independent directors went out of pocket.

Mr John Friedland Editor 